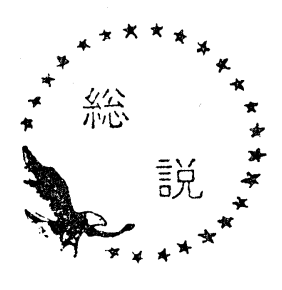

1. 前 説

自然環境保全とか，人間尊重とか，自然における人 間回復の論議はここ 2,3 年とみた盛んとなってきた が, 生物系に関係の深い者には故郷に触れる感のしな いわけではない。

自然界は30億年の歴史のなかで作り上げられた輪回 による高度な調節機能をもつ超大, 超精密機械でもあ 万う。地球上に人類が出現して数万年, この自然生態 系の機能に教えられ, 学び, それに依拠して今日の繁 栄をむたらした。しかし, その恩恵に慣れ, 自然は個 人的な短期的人類のみに在るのではないという反省に 今こそ立たされたものともいえよう。

高度といわれる社会, 文化と深淵広範に発展した科 学, 技術, テクノクラシーに支えられた産業の陰に限 りない人間欲望への消費と放任があるようである。自 然界の貴重で有限である「資源」と，また「エネルギ 一」との濫費が恣にされるならば, 地球上永却の繁栄 の䊼を自から断ち枯渴させるような状態にあること, さらにそれらの過程あるいは結果扮いて暴露し, あ るいは排出される諸々の公害といらフィードバックの 大きいこと、したがってその防除への緊要さがここに 痛感されているといってよい。

このような, 資源の消費と, 環境污損に対応して, 自然界におけるバイオスフィヤー，ことにその内にあ って微生物の生存とその活用が, 資源, エネルギーの 開発に，また廃棄物資の処理と資源的回収の上にいか に関与し, 役割を果すであろうかを, 謙虚に, しかし 希望的に展望することとした。

\section{2. 自然環境保全と科学技術}

地球上では物質の循環あるいは転換の過程がきわめ て巧みに遂げられ, 人類をはじめ動植物, 微生物の一 切は，その循環過程の中で生存条件を作っている。

しかし, 人類の増加と産業の急激な発達が, かかる 循環過程に著しい変化を生じつつある。この一辺には 広範な公害としての影響があり, 他辺には自然界の資 源・エネルギーに依存する人類, 社会への影響があ る。人類の生存に必須な地球上の物質循環, 動植物の
生と死, その間の環境保全, 人類の増加と必然的な社 会生活の複雑化, これらは, 現状, ことに将来, ぞの ような関係になるのであろらか。この間に最小生物で ある微生物がどのような関与を果しており, さらに将 来に大きく期待できるであろらかを論ずることは皮肉 といわねばならない。

\section{2-1 自然環境に叔ける資源}

世界の人口増法種々論議されているが，2000年代に してほぼ70億に達するものと推定されている。一方, 地球上での食糧自給限度は 150 億人分に止まるである らと憂慮されている。人間生存に直接必要な物質エネ ルギーは, 図1亿示すように, 社会活動のそれに約10 倍するものが消費されているといら。これには, 地球 に至る太陽エネルギーの極微量による水 (電力), 光 合成転換質源 (化石燃料, 植物, 動物) が充当される。 しかし莫大とされる化石燃料の消費急増は, 推定埋蔵

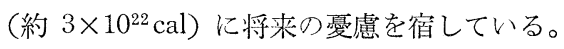

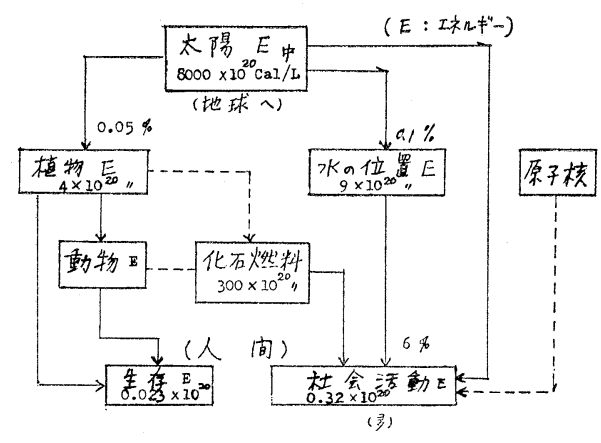

図 1 人間の利用できるエネルギー系

生物にとって重要な元素は, 無生物圈から生物圈 へ, また無生物圈へと循環移行している。自然界にお ける物質の中心である炭素およびこれに次ぐ窒素が, これらの間にバランスし循環している様態を図 2 に示 した。大気中には $\mathrm{CO}_{2}$ の形で約 $6 \times 10^{11} \mathrm{t}$ の炭素が 含まれており, これらは次のよらにして一定の平衡が 保たれている。この $\mathrm{CO}_{2}$ から光合成によって生産さ れる有機物（植物）は年間約 $2 \times 10^{11} \mathrm{t}$ とされ, 同時 


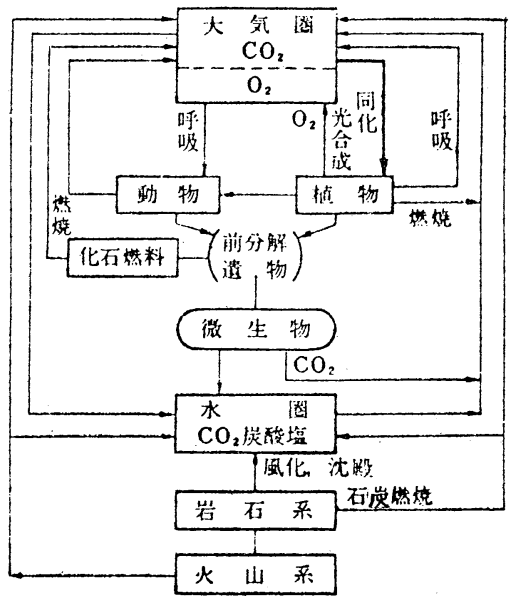

図 2-1 自然界における炭素, 酸素の循環

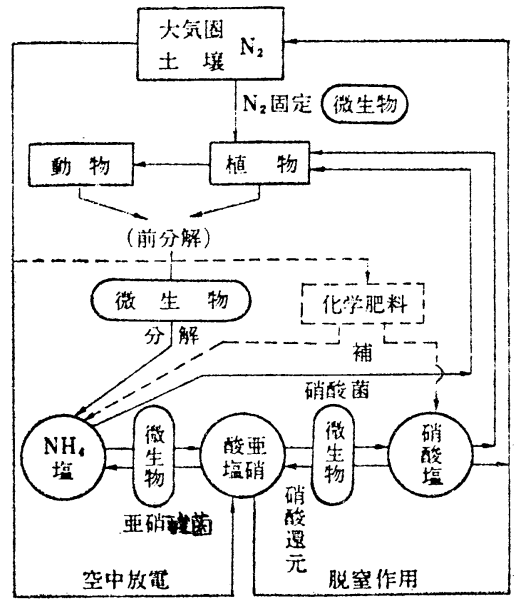

図 2-2 自然界における窒素の循環

にこの際, 年間約 $12 \times 10^{13} \mathrm{t}$ の $\mathrm{O}_{2}$ が遊離されてバ ランス保持の主軸をなしている。この間, 化石燃料は 利用消費されて最終的には $\mathrm{CO}_{2}$ (年間約 $2.5 \times 10^{10} \mathrm{t}$ と推定）と水とになって大気中に戻るのであるが，近 状の消費急増は, 以上の間に大きな失調を来たす惧れ がないとはいえない。

自然界で生成された有機物は, 単なる燃焼によるも のを除けば, 図示のように, ほとんど「微生物」によ って分解され, $\mathrm{CO}_{2}, \mathrm{~N}_{2}$ 水の形で大気, 水圈に戻る ものであることを強調したい。これは自浄作用ともい われ, 輪回の主環をなすものであり, 公害以前の自然 環境保持の姿と称してよい。

$2-2$ 自然環境と科学技術

最近, 地球人類生存の将来を予測して, 現状の推移
にまかせるときに破滅危機の近いことを警告する論が 多くなった。人類の増加とその社会生活の多重化は, 資源的, エネルギー源的に，またさらに環境的に，人 体生理的に, 諸々が悲観的に向かいつつある。限界㐫 る地球とそのバイオスフィヤーに対して, 個人消費は 図 3 に示すように急上昇していることを, アウレリ オ・ベッチエイが指摘しているのもその一例で, 無制 御無自律なテクノクラシーは人類自体を笴地に追い込 みつつあるものと極言している。

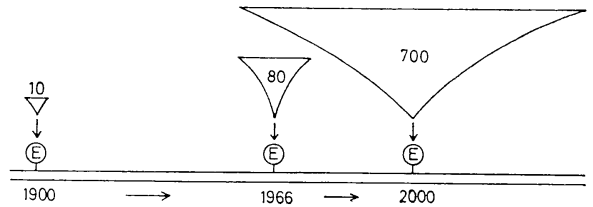

注）人口 $\times 1$ 人当りの消費増加の年次的膨張 Eは地球とバイオスフィヤーの大きさの 有限を示す（技術と経済 1972.1）

\section{図 3 社会活動の多様拡大に伴う人当消費の膨張}

著者はこれらの状態と, さらに将来対応のあり方と を図4 によって解説したい。すなわち, 図中 I (過去) はほぼ 1900 初年代の 状態と思われた 環境であり, II （近状）は破たんの前期的症状を示すむので，これに 対し, III (将来) は諸々の対処によって整屯, 安定化 された姿を推定図示したものである。

ここでは地球の自然環境を, 地上植物を起源とした 生物圈(A) と, 無生物系である地上・地下資源（エネル ギー源を含めて）の無生物圈( $(\mathrm{B})$ と, さらに大気圈(C) と で示し，それらの相関をほぼ図のごとくであるとし た。過去 (I )にあっては, 生物圈の中核的存在である 人間が, その生存と社会活動のための資源とエネルギ 一との取込み, 放出 (返還) を, A, B, C圈との接 触においてほぼ均衡維持の状態で経過してきたものと 見てよい。しかしながら近状(II) 亿到っては，人口増 の上にテクノロジーの躍進による人間社会活動の膨張 の結果, $\mathrm{A}$ みならず $\mathrm{B}, \mathrm{C}$ 圈からの取込みに反し, 自然資源の返還がそしい上に $\mathrm{A}, \mathrm{B}, \mathrm{C}$ 圈への環境污 損, 破壊の状態に突進している姿といってよいのでは なかららか。

これらを反省し, 将来(III)は, 取込み, 返還の収支 を極力均衡させることと環境保持の遂げられた，自然 環境のバランス下にある理想的永却像を確立したいも のと考光る。このためには, 人間の智源から無限に発 展しつつある高度の科学が, 自分たちの, 同時に子孫 永却のための自然環境の保全と，この上での真の繁栄 
I遇去
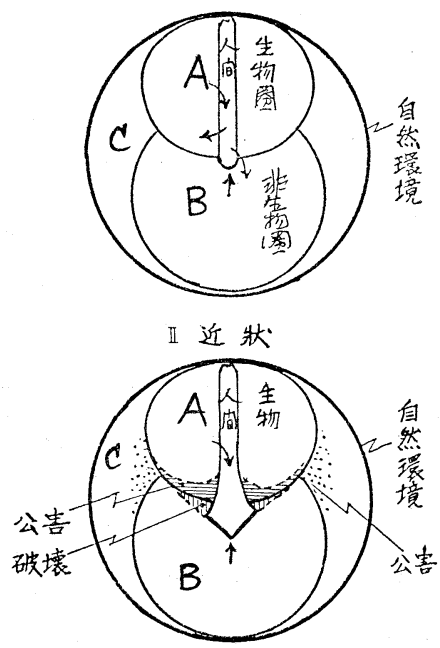

II 将来

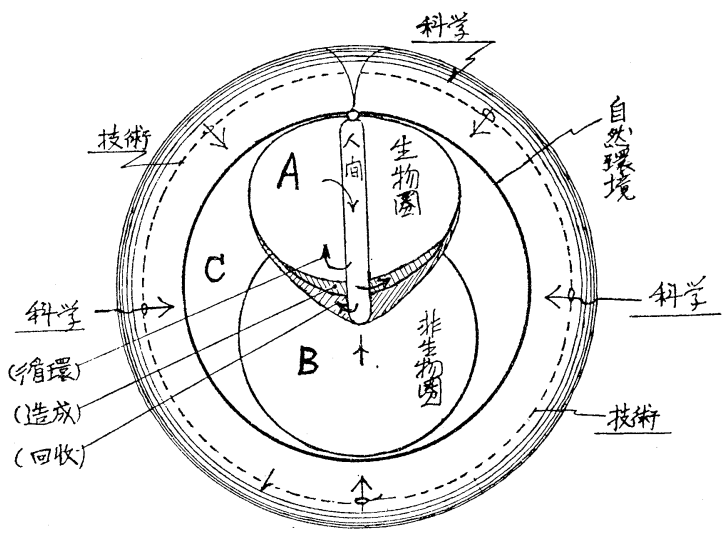

図 4 自然環境の調和と保持

とのために，上述の意における自然環境保全確立への 各科学の推進とそれらの綜合囲繞とによって, また, それらから育生開発された技術とによって, これらの 解決に今こそ努力せねばならないのではなかららか。

\section{3. 資源の確保と微生物の関与}

\section{3-1 資源の確保}

地球上の資源, すなわち地下資源埋蔵量および地上 植物資源の造成速度には限界がある。人類の長期繁栄 を考えるときには, 資源の確保が宿命的な課題となる であろう。一般に広義の資源の開発確保のためには, 図 5 のような関連が要視されるものと思う。

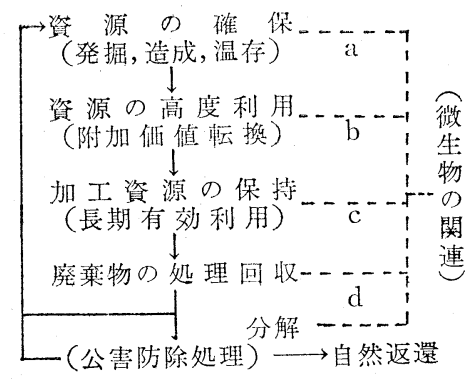

図 5 資源の確保と循環

天然植物系資源の増産, 有機資源の造成, 地下資源 発掘の強化などと同時に，それらの温存を図ることな どによって，資源の確保を恒久的としたい。またその 産業的な使用に当っては, 価值高い効率的転換を企図 し, その生産品は効率的利用と長期保持に努め, 最終
的に使用後の廃棄に当っては, 公害防除と平行して何 らか物質としての回収を図って再資源化するといら一 連の科学・技術の開発が, 自然人類の繁栄への主環と なるのではなかろうか。

以上, 広義の資源確保に対応する微生物側の態度, すなわち微生物の応用その他による関与貢献は, 図中 の右端に示したよらに, 上から順に，a．微生物資源 の造成, b. 発酵生産または微生物機能の利用, c . 生物劣化防除および, $\mathrm{d}$. 微生物機能の利用による処 理, 回収など, 以上の角度から, すなわち総じて微生 物工学技術によって, その多少, 軽重, 遅速はあって も達成しようとするものである。

\section{3-2 資源と微生物応用}

以上は, 自然と資源と生物 (ことに微生物), これ ら相関の断片を述べたにすぎないが，生物科学，その 応用学分野といえる諸生物応用工学や微生物工学など が, 今後, 生産社会に対応して自然環境保全や資源確 保の調和に貢献できる分担は大きいといえよう。これ らを，まず資源確保の上に微生物の広範多岐な関連を 求めることによって, 微生物応用の方向と重要性につ いて図 6 で解説することとする。

1）地上資源の植物は葉緑素により光合成される天 然植物と作物とであって, 従来の発酵原料の主体をな しており, 多くの発酵生産物や菌体タンパクが製造で きる。動物との関連は, 広く生体生理の影響に, また 反趨動物のルーメンとに, あるいは動物排泄物の分解 処理に, 害虫駆除の天敵, 殺虫などに微生物関係を求 


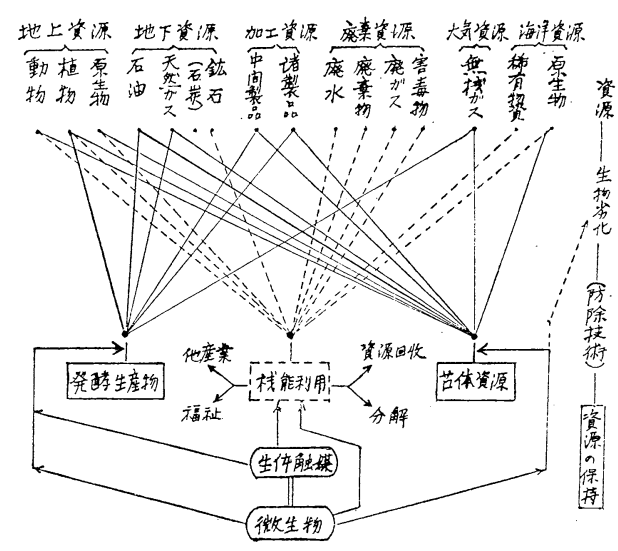

図 6 資源と微生物の関連開発

めることができる。

土壤との関連は, 地上微生物の生存・発生の温床宝 庫である自然界のベッドをなしていることから有用微 生物の探索源である。のみならず地球上の微生物によ る自浄作用の行なわれている大舞台, 豊沃な培地であ ること, また植物生育の養源給与の触媒（土袞微生 物）の媒体をなしていることなど多々が強調できる。

2) 地下資源のうちで化石然料とみられる石油, 天 然ガス, 石炭などは, 安価豊富な微生物工業の新原料 として開発されつつある。菌体資源（例; 石油タンパ ク）の生産のほか, 広範な発酵生産への工業原料とし て登場できる基礎応用研究が相次いで進められてき た。新微生物産業は, 今や炭化水素発酵の時代に突入 しようとしているといってよい。

化石然料のうち等閉視されている石炭が, 微生物に よって再び価值付けられるときのあること（後述）を わたくしは夢とのみ思っていない。

一歩先に, 鉱石からの金属抽出が微生物活用によっ て産業的開発（バクテリヤ・リーチング法として）が 進められていることを注目していただきたい。

3）加工資源というのは，上記の各資源加ら加工生 産される中間製品, あるいは主・副生産物を 2 次的資 源と解するもので，これを原料として微生物利用によ りさらに付加価值製品化することが要視される。石油 化学の酢酸, ガス化学のメタノールなどからの菌体量 産や発酵生産などの応用は目前に迫ってきている。

4) 大気資源というのは, 空気 $\left(\mathrm{O}_{2}, \mathrm{~N}_{2}\right), \mathrm{CO}_{2}$, 水 $\left(\mathrm{H}_{2}, \mathrm{O}_{2}\right)$ その他廃棄発生ガスなどをも含めてこれ を微生物利用の対象と考えるもので, 莫大な放出一途 にある $\mathrm{CO}_{2}$ を，たとえば水素細菌を利用して， $\mathrm{H}_{2}$ を
補助原料として菌体化し，これを有機資源の造成とす る研究もすでに実験室では成功している。

5）廃棄資源というのは, 廃水, 廃ガス, 廃棄物, 廃害毒物など公害源をなす物質を回収し, 再資源する 構想である。これらは「微生物機能の利用」によって 分解または転換する。自然環境の保全と同時に何らか の資源回収を図る上に, 微生物は今後大きく関与する であるうことを確信している。

6) 海洋資源としては, 含有稀有物質の微生物的回 収と, 海水中の特殊微生物の菌体資源化や産業的機能 利用などで将来関連を深くするであろう。

7）諸資源の「微生物劣化」を防除するといら技術 開発が他面にあり，これは資源 (原料・製品) の確保 や形質の維持といら上で資源との関連が重要である。

\section{4. 微生物工学技術による資源の造成}

微生物を活用しての資源の造成には，次の 2 方向が 考えられる。

1）微生物菌体を量産培養することによって, その 主成分であるたん白または油脂, 糖類を有機資源 として食飼料，他産業原料に活用しようという方 向

2）微生物の代謝能を利用することによって，低度 の資源からより高価值な新資源を発酵生産すると いう方向

これらについての研究技術の現状の要点と, 将来展 望を含めて述べる。

4-1 菌体量産による有機資源の造成

食飼料用として微生物菌体を量産して活用する課題 は, ことに石油利用微生物の研究開発によって大きく クローズアップされたといってよい。従来も, 糖質原 料からの菌体 (酵母)置量産して飼料のほか核酸原料, 保健料にも活用されているが，石油，石油二次製品な ぞ炭化水素系の低廉豊富な原料から菌体を広く量産し て精製，または加工し，これを少なくとも飼料に充当 し, 高度なたん白に転換した上栄養食品 (肉, 卵, 乳, 魚など）とする方向は, 低資源の高付価のみならず, 炭化水素から食資源の造成といら面からの画期的な試 みといってよい。

すでに前論したとおり，人口の増加に対する食糧対 処，また栄養上から動物たん白・高力ロリ一要求の急 増の反面に，これら地上資源の供給不足，急迫が目前 に予測されるときの対策として大きく期待される要題 である。

微生物の増殖能のみを利用し，これを量産して有機 資源化する方法には, 従来の技術のほかに, 研究の進 
捗により将来に期待されるものとして, 表 1 , 表 2 亿 示すよらなものが通観される。表中, 炭水化物系以外 は, 、ずれも今後の開発に待つものである。炭化水素 系のらち,n-パラフィンからの酵母量産が現在の中心 課題であって, n-パラ $1 \mathrm{t}$ から乾燥菌体（たん白50 $60 \%) 1 \mathrm{t}$ 以上を滞留時間 $4 \sim 8$ 時間の連続法によっ て液中濃度約 $2 \mathrm{~g} / l$ で生産するといらのが現害性ある データとなりつつある。生産コスト中の原料費 $(n$-パ ラ）は，30 35\%以内であることが要求され，製品は 当面䬰料, 飳料として利用されることが期待されてい る。炭化水素系には, このほか, 天然ガスのメタン, またはブタン，プロパンが，また石油二次製品ではメ タノール，酶酸がそれぞれの特徴を活かしての研究と して進捗中である。

このほかには, 藻類の単細胞系のものでクロレラの
表 1 諸原料（基質）からの菌体量産 I

\begin{tabular}{|c|c|c|}
\hline $\begin{array}{l}\text { 原料（基質） } \\
\text { (炭化水素) }\end{array}$ & 名（例） & 菌体得量 \\
\hline glucose & Sacharomyces & $58 \%$ \\
\hline $\begin{array}{l}\text { 糖 蜜 } \\
\text { (炭化水素) }\end{array}$ & Hansenula, Candida & $45 \sim 60 \prime \prime$ \\
\hline n-パラフィン & Candida, Torulopsis & 97 \\
\hline " $\mathrm{C}_{14}$ & $\prime \prime \quad 11$ & $85 \prime \prime \prime$ \\
\hline "I $\mathrm{C}_{14 \sim 18}$ & $\prime \prime$ & 103 \\
\hline$\prime \prime \quad \mathrm{C}_{14 \sim 17}$ & " & 132 \\
\hline ガスオイル & & $91 \prime \prime$ \\
\hline × タ $ン$ & Ps. methanicus & $8 \sim 25 \mathrm{~g} / l$ \\
\hline エタン & "I & "I \\
\hline プロパン & "l & " \\
\hline ブ タ ン & $\prime \prime$ & $\prime \prime$ \\
\hline
\end{tabular}

表 2 諸原料（基質）からの菌体量産 II

原料（基質）菌名（例）

菌体得量

石油二次製品

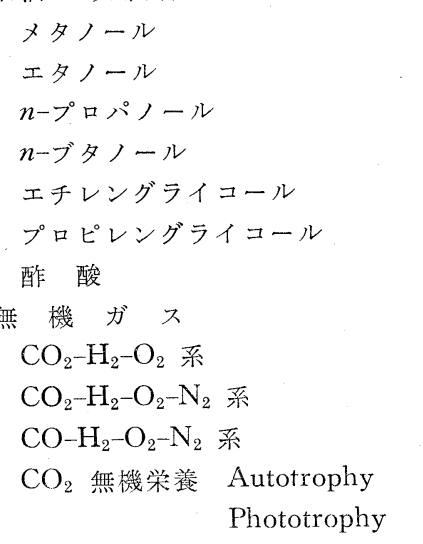

$\mathrm{CO}_{2}-\mathrm{H}_{2}-\mathrm{N}_{2}$ 系 (慻気)

植物プランクトン

Candida

$35 \mathrm{~g} / \mathrm{l}$

Pichia

$34 \mathrm{~g} / \mathrm{l}$

Arthrobacter "

Arthrobacter

Candida, Hansenula

$13 \mathrm{~g} / \mathrm{l}$

Heterogenomonas ruhrandii

$3.5 \mathrm{~g} / \mathrm{l}$

Heterogenomonas

$2.4 \prime \prime$

Hetr. S. 17

緑 藻 類 Chlorella

$1.5 \prime \prime$

15-20 t/acre

藍藻 Spirullina

ケイ䍄 Diatom

"I

光合成細菌

Photosynthesis

" Chromatium sp.

小型動物プランクトン, 原虫類

諸廃水（有機質）

諸微生物

担子菌 Basidiomycetes

有機質栄養源

諸栄養源

組織培養

光合成による量産がすでに同目的で課題となったが， コスト面で停滞し, むしろ糖, 酢酸からのへテロ培養 による開発方向が興味とされる。淡水, 海水藻類 (図 7 ) のちちには, このほかにも人工量産向きのものが 着目されて将来に期待が連がる。光合成系の菌体を量 産する着目は, 他方向に進展し, 新しい藻類, 光合成 細菌などからの研究も進められてきている。有機質廃 菓資源ことに廃水をその污水対処と併行して, これら
から飼餌料向き菌体を生産し回収するといら着眼は, 廃水处理と資源の回収, 再造成の三辺を満たすもので あって, 廃水の種類, 環境などによっては現実性ある ものとなるであろう。

有機質資源の造成で将来の技術開発に嘱望されるも のとして, 無機ガスからの微生物菌体の生産といらこ とを挙げたい。たとえば $\mathrm{CO}_{2}$ または $\mathrm{CO}$ とこれに $\mathrm{H}_{2}$ を組み合わせた原料ガスから（他注微量のミネラ 


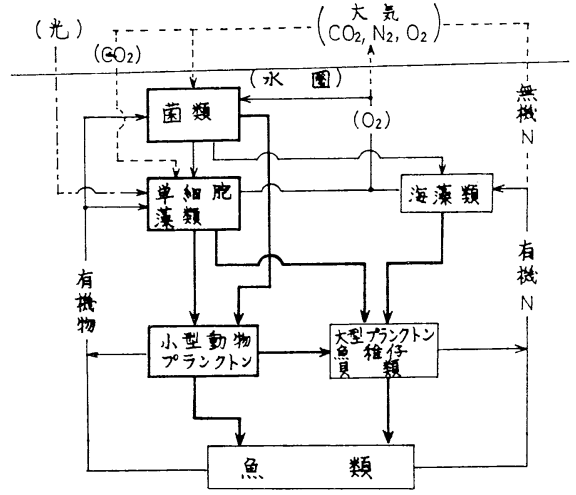

備考：太線は捕食餌料経路，細線は 同化，栄養循環系路

\section{図 7 海洋における生物系の循環経路}

ル水溶液) 菌体を培養することに，最近微工研の大山 らが成功している。この際の菌体は水素細菌 (Heterogenomonas) の一種であって, 菌体増殖の機作の要 点は次のと㧍りと解訳される。

$$
\begin{gathered}
4 \mathrm{H}_{2}+\mathrm{O}_{2}+\mathrm{CO}_{2} \longrightarrow\left(\mathrm{CH}_{2} \mathrm{O}\right)+3 \mathrm{H}_{2} \mathrm{O} \\
0.1\left(\mathrm{CH}_{2} \mathrm{O}\right)+0.1 \mathrm{O}_{2} \\
\longrightarrow \\
\longrightarrow 0.1 \mathrm{CO}_{2}+0.1 \mathrm{H}_{2} \mathrm{O} \\
(1)+(2) \quad 4 \mathrm{H}_{2}+1.1 \mathrm{O}_{2}+0.9 \mathrm{CO}_{2} \\
\longrightarrow 0.9\left(\mathrm{CH}_{2} \mathrm{O}\right)+3.1 \mathrm{H}_{2} \mathrm{O}
\end{gathered}
$$

この場合の水素細菌は水素に酸化的に作用し, その 際の発生エネルギーを利用して菌が $\mathrm{CO}_{2}$ を同化する わけで, これらガスの吸収比は $\mathrm{H}_{2}: \mathrm{O}_{2}: \mathrm{CO}_{2}=4.5$ : 1.2:1 のごとくである。さらに窒素を空気中からの
ものに求めること，すなわち $\mathrm{CO}_{2}-\mathrm{H}_{2}-\mathrm{O}_{2}-\mathrm{N}_{2}$ 系か らの菌体生産にも実験的に成功している。培養時間 (generation time で数時間) は他法に比しとくに長 時間ではないが, 菌体収量 $(3 \mathrm{~g} / l)$ は今後の研究によ って向上しうることと思う。

これらは「石炭」の再資源的利用の可能性にも通ず ることにならないかと考える。石炭の微生物的利用も 将来無縁ではないことになろうが，ガス燃料として企 業性ある石炭ガスの組成は，たとえば然用ガスの例に は $\mathrm{CH}_{4} ; 32, \mathrm{H}_{2} ; 50, \mathrm{CO} ; 8$ その他が，また完全ガ ス化ガスの例には $\mathrm{CH}_{4} ; 6, \mathrm{H}_{2} ; 52, \mathrm{CO} ; 28, \mathrm{CO}_{2} ; 8$ その他が，また発生炉ガスでは $\mathrm{CO} ; 30, \mathrm{CH}_{4} ; 3$, $\mathrm{H}_{2} ; 16, \mathrm{~N}_{2} ; 47$ その他のごときがそれぞれ知られ，

C源の他に $\mathrm{H}_{2}$ を多含し，また多含させることも見込 まれるので, 上述のように,ガス化した石炭資源からの 菌体量産への通路を開拓することができないかは, 著 者には興味ある将来の課題であるように考えられる。

何れにするも，廃気ガス，最終分解物とみなされる $\mathrm{CO}_{2}$ などを炭素源として生物的有機質資源を工業生 産し得る可能性を解示したことは，資源の回収，造成 という面で生物圈保全に将来への希望を託せるもので あり注目してよい。

以上は主としてたん白生産を主目的とした研究であ るが，菌体の量産目的には，将来油脂資源，糖資源 (ことに多糖類) の生産をも含めて考えるべきであ る。これらの微生物利用による石油などからの生産研 究もすでに着手されているが，ここではその一端を例 示（表 3) するに止める。

4-2 発酵生産による資源の付加価值化

表 3 微生物による油脂, 糖資源の生産

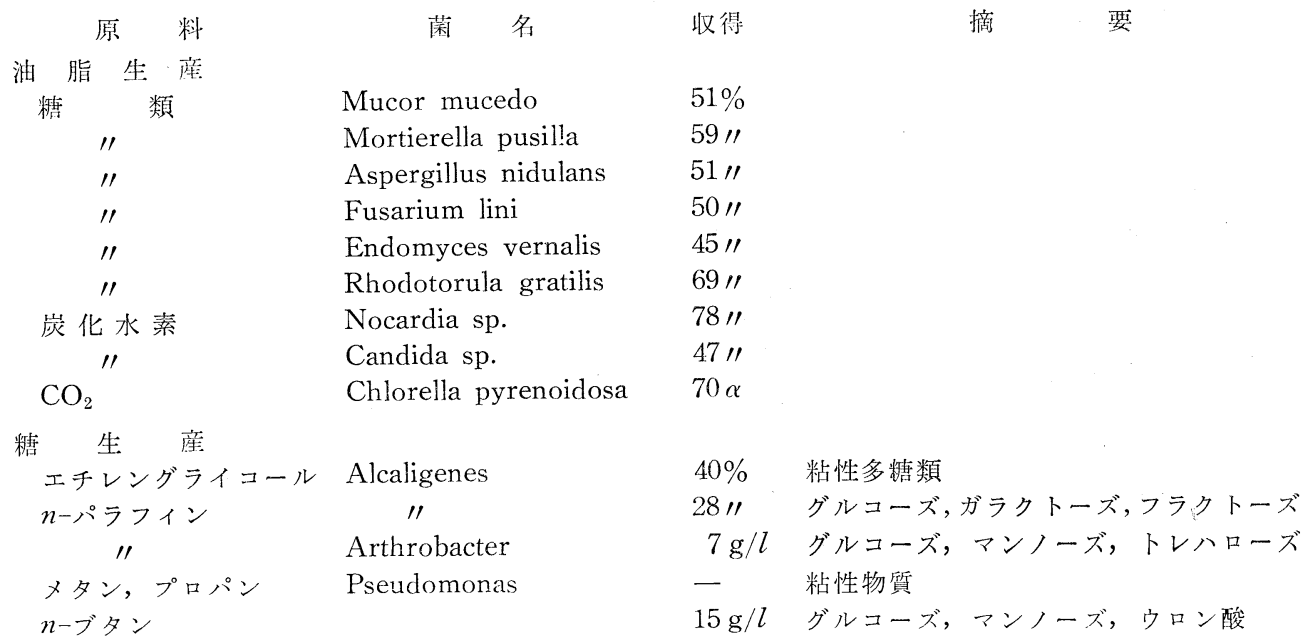




\section{表 4 炭化水素の発酵生産による資源付価}

発酵生産物

アミノ酸

$L$-グルタミン酸

$L$ リリヂン

Lーチトルリン

$L$-フェニルアラニン

Lーオルニチン

Lーバリン

Lースレオニン

L-アラニン

グリシン

Lーホモ七リン

生理活性物質他

ビタミン $\mathrm{B}_{2}$

"l $\mathrm{B}_{6}$

"l $\mathrm{B}_{12}$

ビオチン

エルゴステロール

チトクロム $\mathrm{C}$

$\mathrm{CoQ}$

$\mathrm{CoA}$

ジベレリン

オロット酸

オロチジン

核酸系物質

イノシン

リボ核酸

有機酸

クエン酸

イソクエン酸

$\alpha$ ーケトグルタール酸

ピルビン酸

乳 酸

フマール酸

ベンゾイックアシド

p-トルイル酸

クミン酸

フェナジンモノカルボ

ン酸

ジビコリン酸
炭素源

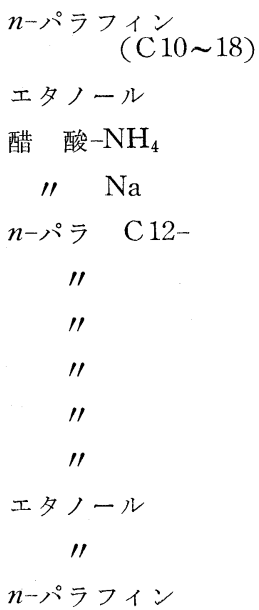

n-パラフィン

"I

"I

n-ウンデカン

n-パラフィン

"I

n-ヘキサデカン

n-パラフィン

n-パラフィン

"I

"1

n-パラフィン

n-パラフィン

"1

n-パラフィン

"

"I

プロパン, ブタン

1,2-プロパンジオル

n-パラフィン

トルエン

p-キシレン

pーサイメン

nーパラフィン

"
生産収量

菌名

$20 \sim 75 \mathrm{~g} / l \quad$ C. hydrocarboclastas

60 " Brevibacterium

23 " $\quad$ B. flavum

20 " B. lactfermentum

10 " B. ketoglutamicum

8 " Corynebacterium

10 " Corynebacterium

$9 \prime \prime$

6 " Arthroparaffinius

6 " Arthro. p.

$2.5 \prime \prime$

C. hydrocarboclastas

$2.5 \prime \prime$

$12 \prime \prime$

C. glutamicum

$110 \mathrm{mg} / \mathrm{l} \quad$ Pichia

$1 /$ Candida

1 " Nocardia

20 " Pseudomonas

70 " C. tropicalis

13 " C. lipolitica

8 " Achromobacter

65 " Candida

50 " Giberella

$6 \mathrm{~g} / l \quad$ A. paraf.

$3.5 \mathrm{~g} / l$

1-2 $\mathrm{g} / \mathrm{l} \quad$ Arthrobacter

$1.5 \mathrm{~g} / \mathrm{l} \quad$ Coryne. p.

$1.2 \% /$ cell C. tropicalis

$28 \mathrm{~g} / l \quad$ Arthrobacter

20 " Arthrobacter

$40 \mathrm{~g} / \mathrm{d} l \quad$ Candida

$20 \mathrm{~g} / l \quad$ Mycobacterium

9 /" Arthrobacter

40 " Candida

$25 \prime \prime$

19 " Pseudmonas

6 " Pseudmonas 
微生物の発酵によって有用物質を生産することを発 酵生産といい, 醇造, 発酵食品のほかに, 有機酸, ア ミノ酸, 抗生物質, 生理活性物質, 酵素などが工業生 産される。最近は, この原料に従来の糖質のものより はるかに低廉な石油系一次, 二次製品を使用する研究 が表 4 に例示するように進み，工業化されるものもあ る。これらは資源の高付価化への開発として新しい領 域を築くこととなろう。

\section{5. 微生物工学技術による廃充物処理}

公害は, 人類の特定地域的な集中過密化々, 産業社 会が不調和のまま放任され, 総じて環境破壊のままに 放置されている非文化的, 非科学的さらに非自然的な 事態なものと解してよい。人自からが招いた公害は， 人自からの道義と科学とによって解決され祀ばならな い。廃棄物公害の有力な克服手段が，実に微生物によ る自浄作用の解析とその作用に基づく人為的制御によ る管理といらことであることは皮肉なことといわざる
をえない。

産業, 社会活動から排出される廃棄物公害の対象に 法，1）液状の産業廃污水，2）固形状の合成高分子化 合物，3）ガス状の排ガス，燒却ガスなどにわたるも のが考えられる。これらの微生物機能を利用する分解 処理, さらに回収処理について現状と将来の期待など を概説したい。

\section{5-1 産業廃水の微生物処理}

一般に廃水を処理する方法は大別して, 物理化学的 方法と生物学的方法があるが, 両者の組合せによるも のもある。しかしながら, 有機質の廃水の処理には, 微生物の酸化的分解作用を利用した活性污泥法, 撒水 沪床法あるいは嫌気的分解を利用したメタン発酵法が 適当することは，周知のところとなってきた。

これらを総合して，体系的に処理系統を例示すれば 図8のようになる。

また微生物による好気・嫌気両分解法の機作の要点

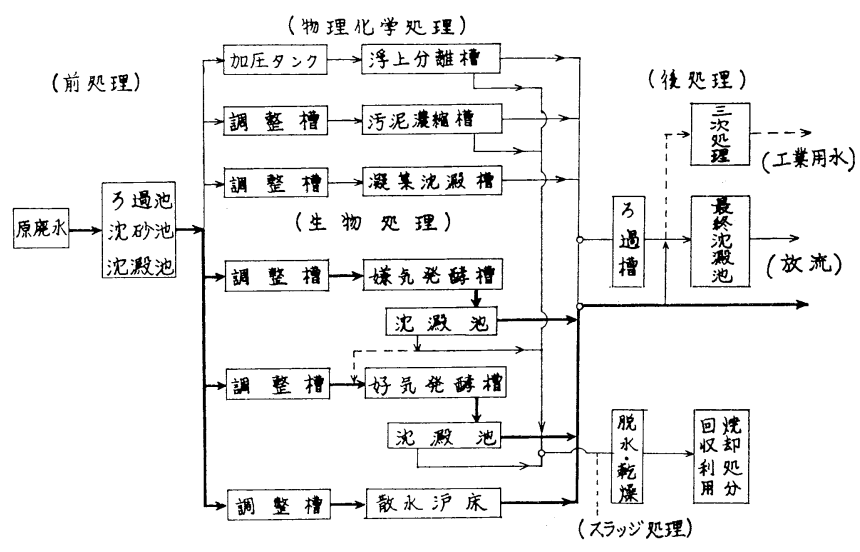

図 8 廃水処理諸法のフローシート

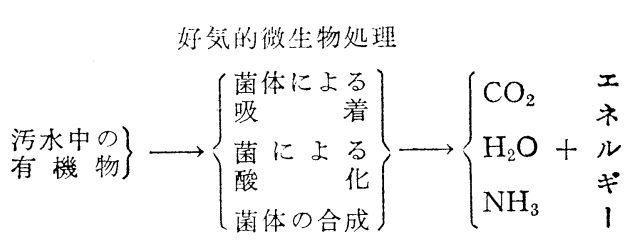

嫌気的微生物処理

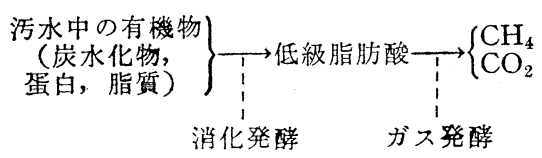

図 9 微生物による分解道程
は図 9 に示すごとくである。

活性污泥法には標準型のほかに改変された段階曝気 式, 接触安定化式, 高速通気式, 安全混合式, その他 がある。また，これらメタン発酵, 活性污泥法によっ て諸廃水を処理した場合の成績を例示すれば, それぞ れ表 5 , 表 6 の如くである。

産業廃水処理技術については, なお菌群の生態, 生 理, 作用機作, 解媒的条件, ことに位相の解明などか ら連続発酵へのシステム工学へ完成する基本的, 体系 的研究をさらに強化することによって, 効率, 施設費, 管理の上に今後改良余地のあることが認められる。

5-2 合成高分子廃棄物の微生物処理

各種の高分子樹脂製品は, 社会, 産業, 生活物質の 


\section{表 5 各種産業廃水のメタン発酵による処理成績（微工研）}

廃水の種類

原廃 水

有機物 BOD

処 理 量

ガ ス 発生 量

BOD

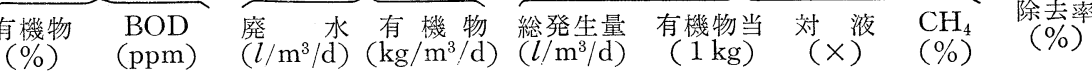

アルコール蒸溜

3. $0 \sim 20,000 \sim$

$150 \sim 250$

3. $0 \sim 20,000 \sim$

$80 \sim 125$

$5.5 \sim 605$

$3,000 \sim$

$500 \sim 700$

$10 \sim 30$

"1 (中温発酵)

1. $4 \sim \quad 6,000 \sim$

ブタノール蒸溜

$300 \sim 400$

$2.0 \sim 3.0$

$80 \sim 90$

抗生物質廃水 (ペニシリン)

$0.92 \quad 10,000$

250

6. $0 \sim 6$.

$1,000 \sim$

$500 \sim 700 \quad 10 \sim 23 \quad 50 \sim 60 \quad 95$

洗毛廃水

$\begin{array}{cc}2.0 \sim & 9,000 \sim \\ 0.4 & 15,000\end{array}$

400

2.3

$2,000 \sim$

$350 \sim 450 \quad 10 \sim 13 \quad 50 \sim 55 \quad 50 \sim 80$

ステフェン廃水

2. 35

9,100

175

9. 0

480

208

1. $9 \quad 50$

86

わらパルプ廃水

1.8

COD
$(14,000)$

300

4. 11,700

180

$4 \sim 6 \quad 75$

60

5.4

2,500

414

$9.7 \quad 79$

83

紙パルプ工場微

$\begin{array}{cccccc}1.8 & 600 \sim & 240 \sim 550 & - & 70 & 40 \sim 70 \\ \text { (繊維) } & 1,500 & \text { 繊維) }\end{array}$

8.35

COD

\section{表 6 各種工場廃水の活性スラッジ法による処理成績（微工研）}

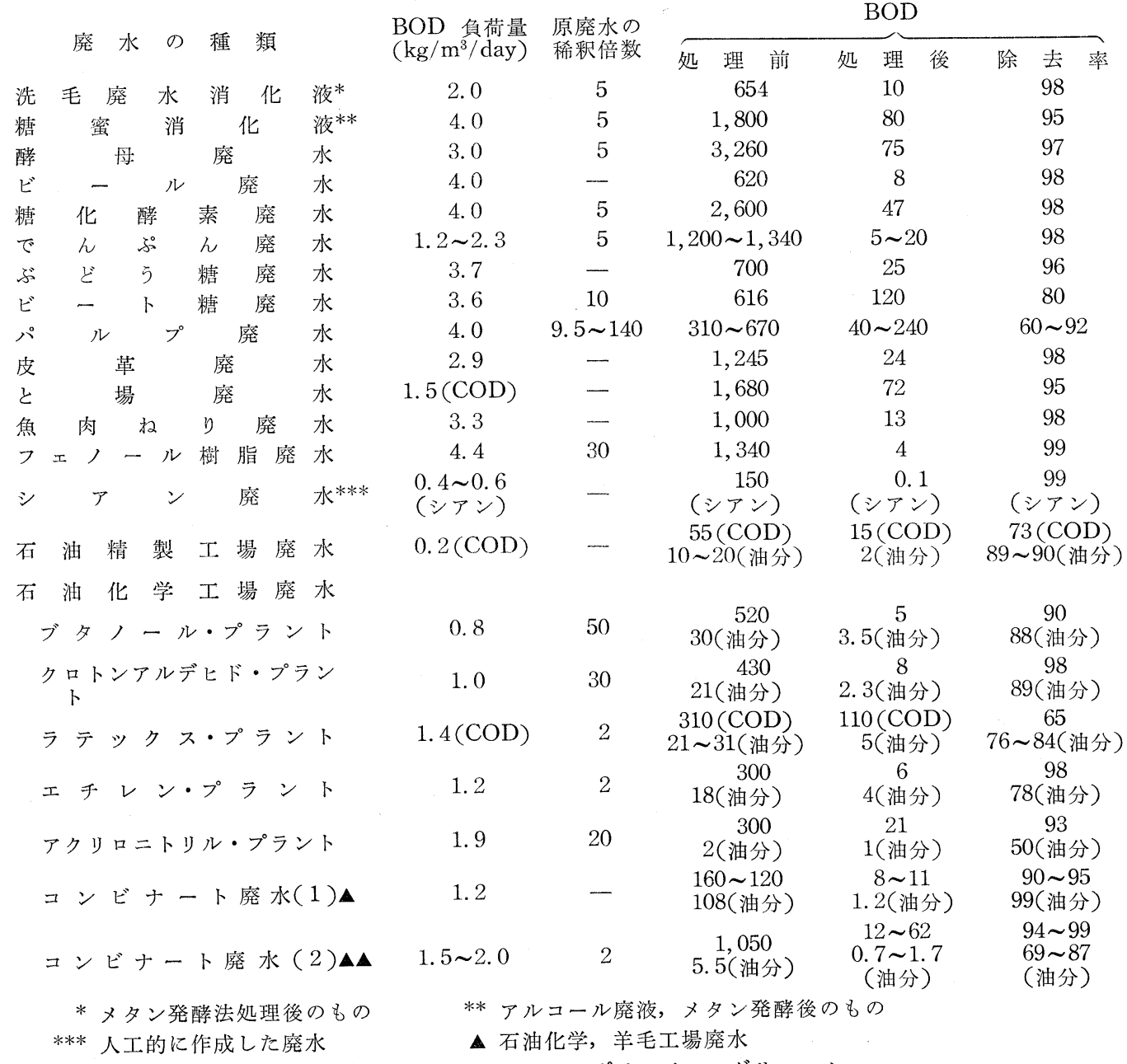

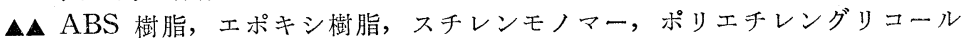


上で多種多様にわたって便宣と恩恵を与えているが， これらは元来自然界に存在しなかった物質で, 強じん ・耐性であるので廃棄後の天然高分子のように自然分 解によって容易には消滅することがない。ここに，永 続的・広域にわたる廃棄物公害発生の原因がある。20 世紀後半の人類の生んだ自業の宿命に悩む縮図ともみ られよっ。

世界に先駆しているわが国の生産・需要と，したが ってその廃棄・処理の様相は, 図10に示すとおりであ って, 現状の推移加ら, その原料, 加工, 使用, 流 通, 消費にわたって, 都市, 農村, 陸海にはんらんし ようとする惧れがある。

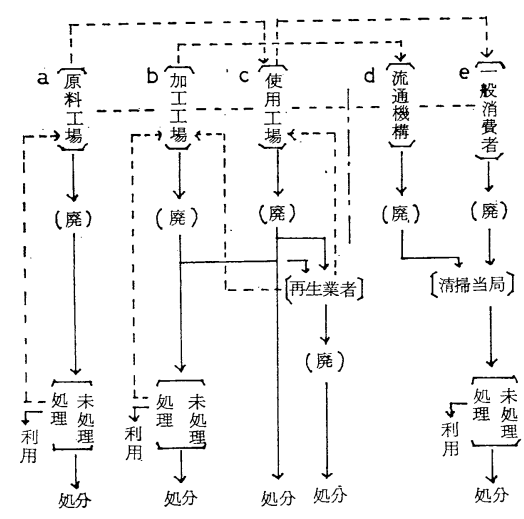

備考：1）社団法人資源化技術協会，炤46年 2 月 の調查

2) プラスチックの廃棄物(廃)推定はa， b , c の計約 1,000 工場で 18 万 t であり, $\mathrm{d}$, e から約10倍の 220 万 $\mathrm{t}$ といわ机る。

3) 図中の処分の方法とは, 大気拡散（焼 却), 地上投萧, 海上投率をいう。

4) a, b , c の廃菓処分については, 立 法後 $\mathrm{a}, \mathrm{b}, \mathrm{c}$ 側の責任となる。

図10 プラスチック廃衰物の処理・処分の主系統

この廃棄物処理の現状は, 地上投衰, 海上投棄, 焼 却などに頼っているのが実体であって，基本的な技術 は内外に確立されていない。この対応としては, 最 近, 次の線上での解決が要望されている。

1) 自己分解プラスチックの開発

2）微生物による分解

3）薬品による分解

ここにも微生物に依存されるものの大きいことが判 るのであるが，かつて自然界微生物の当面しなかった 基質であって, きわめて難題である。微生物と合成高 分子・プラスチックとの関連を辿れば, これらの微生 物劣化 (Biodeterioration), すなわち，かび害や細菌
腐食に対する防除という面での研究・技術が進められ てきたのみである。廃棄物処理として積極的分解への 微生物応用研究は, ようやく,ここ数年にして着手さ れたばかりである(表7)。

\section{表 7 高分子プラスチックの生分解に関する研究}

\begin{tabular}{|c|c|c|}
\hline 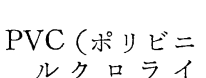 & $\begin{array}{l}\text { Fungi, Bacteria } \\
14 \% \text { in } 4 \text { week }\end{array}$ & $\begin{array}{l}\text { H. R. Hity } \\
\text { (1965) }\end{array}$ \\
\hline ド) & $\begin{array}{l}\text { Pseudomonas } \\
23 \% \mathrm{PVC}_{\mathrm{C}}\end{array}$ & $\begin{array}{l}\text { R. Gurges } \\
\text { (1965) }\end{array}$ \\
\hline $\begin{array}{l}\text { ポリビニルアル } \\
\text { コール } \\
\left(\mathrm{PVA}, \mathrm{PVA}_{\mathrm{C}}\right)\end{array}$ & $\begin{array}{l}\text { Bacteria, Yeast, } \\
\text { Fungi } 124 \text { spe- } \\
\text { cies }\end{array}$ & $\begin{array}{l}\text { J. Toorn } \\
\text { (1969) } \\
\text { T. Suzuki } \\
(1968)\end{array}$ \\
\hline
\end{tabular}

ポリウレタン $\begin{array}{r}\text { Pseudomonasaer- } \\ \text { oginosa, Clabo- }\end{array}$ P. R. T. Darby sporium resina (1968)

合 成 ゴム （加硫天然ゴ ム, イゾム)

W. J.

Bacteria, Fungi (1969)

ブナ N

K. Kereluck (1963)

これらの研究の現状から高分子廃棄物への生物処理 の技術特徴として, 次のことが推定されてくる。

1）高分子ポリマーは最も難分解で, うちでもエー テル型が至難, エステル型はやや難とみられる。

2) プラスチック添加の可塑剤・安定剂は比較的に 分解されやすく, 分解物は炭素栄養源となる。

3）分解に普遍性ある菌は求められず, 高分子型別 に適応する菌の検索と利用が図られる心゙きであ る。

4) 自然界の生体高分子および石油微生物の分解能 の構造を参考とし, また既知分解能ある菌と高分 子構造との関連を体系的に研究して, 易分解性の 構造ある新たな製品を開発することが抜本的な解 決となろら。

最近の光崩壊性樹脂 (ポリオレフィン系) の研究開 発なども，また PCB 代替物質といわれるアルキルナ フタレン系物質の開拓なども，この方向への可能性を 生みだしつつあるものとして注目される。

当面, 微生物によるこの廃棄物処理法の技術を示す ことはできないが, 埋立処理法, 推肥化法や土壤改良 剂に転用する方法などに菌の積極的活用を図ることは 実用性があるであろら。しかしながら, 貴重な化石然 料 (石油) 資源の消費の上に立つこの廃棄物は図 11 に 示すように, 物理化学的処理のうえで, また資源的回 収再利用の上で, 最終的には微生物によって自然の輪 回に戻すこととしたいのが念願である。 


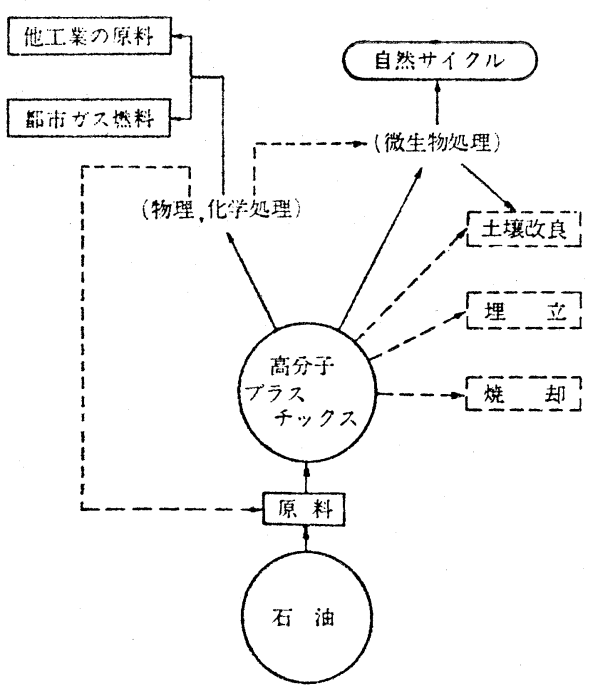

図11 高分子廃棄物公害人の対処

5-3 合成有機害毒物質の微生物的分解

最近の応用化学の進歩により, 有機合成, 石油化学 その他の諸化学工業の発展に伴って合成される有機物
質, たとえば合成高分子中性洗剤, 各種農薬, 殺菌剂 などは, 社会生活, 産業, 農業に多大な貢献を果たし ている。ところが，これらが使用された後に無責任に 放置, 放棄されるときには, 意外侸社会環境の上に悪 影響を与える。これらは, 以上の種類とその使用が多 くなり, 過密環境においてさらに著しい公害状態を露 呈することになった。これと同性質のものに高分子プ ラスチックなどの廃棄物があり, いずれも廃棄段階に 至った場合に公害原因としてこれを害毒物質と解され る。したがってこれに対応する処置が微生物機能の応 用面にも期待されるに至った。

本来, これらの物質沙生物経過と無縁に生産され たもので, 自然界での而性が強く, 微生物によっては 反って生育抑制, 死滅させる性質のものすらあり, 自 然界での微生物的分解は至難なものといわれている。 しかしながら, それらの公害防除対応として微生物分 解によって害毒性を軽減, 解消する研究は, 表 8 のよ らに最近とみに進んできた。地上, 海水中での微生物 による自然分解を促進する方法や, 活性污泥法などの フローラによる強制分解プロセスの発展から, より強

\section{表 8 害毒性有機廃辌物資の微生物処理の事例}

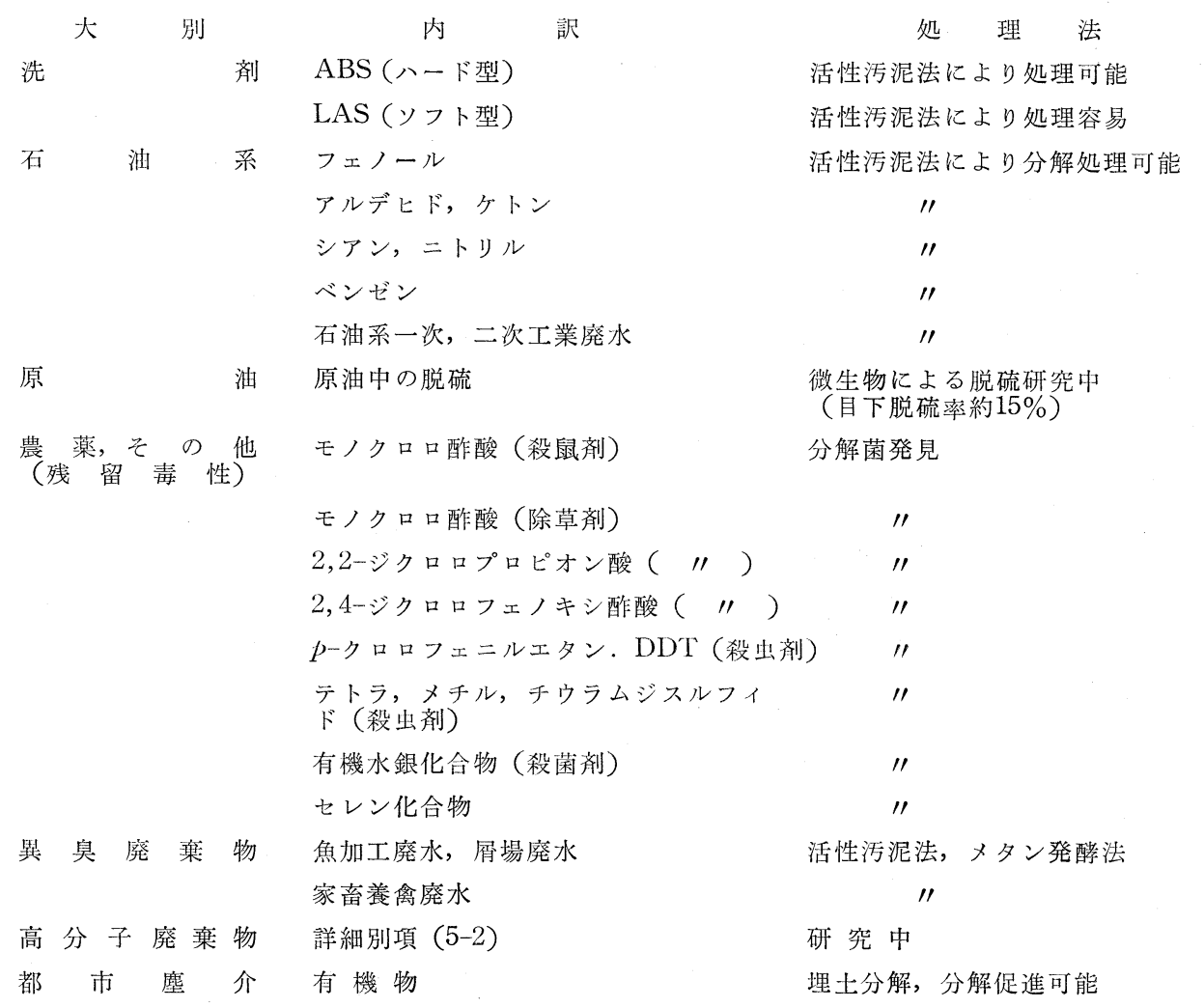


力な菌の検索と，その活用の制御下において，それら

の分解を促進する方法などの研究も進められてきてい る。

今後, 化学合成新物質の生産には, $\mathrm{PCB}$ の前䡴を

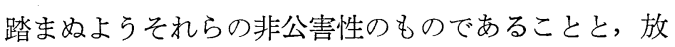
棄後の自然, 微生物分解性のあることなどとを要視し て検討し考慮さるべきであろう。

5-4 ガス状廃棄物の処理
複雑多様な対象であるが，石油系に起因する $\mathrm{SO}_{2}$, $\mathrm{CO}_{2}, \mathrm{CO}$ などの污染害が主問題であろう。微生物に よる原油脱硫はいまだ至難であるが，その研究は依然 要題として残される。 $\mathrm{CO}_{2}$ は生物光合成または無機 栄養微生物の炭素源として, 前者では一部応用化が, 後者では前述のように実験室段階での可能性を見出し ている。将来, 廃棄ガスの処理と資源回収, 造成を並 立させる夢として，今後の研究に託するものが多い。

\title{
Development of Natural Resources and Treatment of Industrial Wastes by Means? Microbial Engineering
}

\author{
by Saburo Shichiji
}

SYNOPSIS :--Reconsidering the harmful influences introduced by the recent technology, the preservation of environmental nature is becoming the important subject to the mentioned technology in this decade.

Therefore, it should be stress on the following themes such as 1) the developmental project for the maintenance of material and energy resources, and 2) the treatment of wastes and the recovery of resources during production and consumption processes.

In this review, several facts and appearent contributions obtained by various kinds of microorganisms have summarized. It would be say that 1) new fields of biomassproduction and fermentation production, and 2) wastes treatment and resources recovery using with microbial functions were disussed concretely in this article. 